Relationship value in business-to-business markets: a replication and extension of Ulaga and Eggert's (2006) study

\begin{tabular}{|r|l|}
\hline Journal: & Journal of Business and Industrial Marketing \\
\hline Manuscript ID & JBIM-07-2019-0320.R3 \\
\hline Manuscript Type: & Original Article \\
\hline Keywords: & $\begin{array}{l}\text { relationship value, Relationship marketing, business-to-business } \\
\text { markets, replication }\end{array}$ \\
\hline \multicolumn{2}{l}{} \\
\hline
\end{tabular}

SCHOLARONE
Manuscripts 


\title{
Relationship value in business-to-business markets: a replication and extension of Ulaga and Eggert's (2006) study
}

\begin{abstract}
Purpose - Ulaga and Eggert (2006a) examined a framework of relationship value in business markets. The current research replicates this study to show that relationship benefits are more important than relationship costs when it comes to choosing a main supplier. This research also extends the original study by hypothesizing that the development of relationship value has a positive impact on relationship marketing outcomes, thus providing evidence of the nomological validity of the original scale.
\end{abstract}

Design/methodology/approach - The study used empirical data from purchasing managers in manufacturing firms in the UK. The research instrument was a structured questionnaire. The study adopted a close replication to Ulaga and Eggert (2006a) using a rather similar context and methodology for comparison reasons.

Findings - Relationship benefits are more important than relationship costs when it comes to choosing a main supplier. Cost competitiveness is a necessary but not sufficient condition to differentiate in business markets. Value dimensions relate significantly to relationship marketing outcomes, providing evidence of the nomological validity of the original scale.

Research limitations/implications - Given the dynamic nature of the relationship value construct, future longitudinal research could offer useful insights on how value is created over time.

Practical implications - Although internal cost reduction, which can ultimately lead to price reduction, should not be ignored, suppliers should focus on creating value through personal interaction, service quality, product enhancements and delivery efficiency. 
Originality/value - The findings provide support for Ulaga and Eggert's (2006a) conceptualization, indicating that relationship value is not merely a theoretical construct viewed on a high level of abstraction but rather can also be empirically measured.

Keywords: relationship value, relationship marketing, business-to-business markets, replication

Paper Type: Research paper 


\section{Introduction}

There has been an increasing recognition among scholars and practitioners that the development of superior customer value can be a source of differentiation in business relationships. As relationship marketing became popular and there was a common belief that relationships were important, the discussion of customer value started to shift from the value of the objects of exchange in relationships (products/services) to the value of the relationships themselves. Ulaga and Eggert (2006a), in their seminal work, conceptualize relationship value as a trade-off between the benefits and costs involved in an exchange, distinguishing between three levels at which these drivers operate (i.e., core offering, the sourcing process and customer firms' internal operations). They found that service support and personal interaction are the core differentiators. They also found that price shows the weakest potential for differentiation. This approach casts value creation in terms of customer perception; that is, value lies in the "eye of the beholder", and its roots can be found in the service quality literature (e.g. Parasuraman et al., 1991). Consequently, as customers' needs and preferences evolve, the dimensions that drive value creation and/or their relative importance are also likely to change over time. This partially explains why, to date, there is no general agreement among researchers on what value creation in business relationships actually involves. This lack of consensus in the customer value literature calls for replications of the Ulaga and Eggert (2006a) conceptualization of relationship value.

This article therefore has two purposes. First, it replicates Ulaga and Eggert's (2006a) study, using their research instrument in a comparable but different context. In line with their article the study analyses the psychometric attributes of the relationship value measure and assesses the relative importance of its dimensions. Second, this study attempts to answer the call from Ulaga and Eggert (2006a, p. 133) that "integrating value into the nomological network of relationship marketing remains a promising opportunity for further research.” The 
study extends Ulaga and Eggert's (2006a) study by testing the linkage between relationship value and the relationship marketing outcomes of customer loyalty and customer business performance. This finding not only provides support for the underpinning of Ulaga and Eggert's (2006a) study that value creation suggests sources of competitive advantage in business relationships, but also complements the literature on relationship marketing by providing insights into the research question: what customer-focused outcomes are most affected by customer relationships (Palmatier et al., 2006)?

The study uses data from 228 purchasing managers in manufacturing firms in the UK. Data analyses include structural equation modeling (SEM) and fuzzy-set qualitative comparative analysis (fsQCA). While SEM focuses on studying the net effects of individual antecedents on the dependent variables, fsQCA enables examination of different configurations of conditions that give rise to the outcome under investigation and allows identifying the necessity and sufficiency of the independent variables for the outcomes of the study (Ragin, 2008).

We believe that our study contributes to the emerging literature on customer value in business relationships. From a theoretical perspective, the study provides further evidence that Ulaga and Eggert's (2006a) conceptualization suggests a reliable and comprehensive measure of relationship value in business markets. This is important because studies of customer value assessment in business markets remain scarce (Lindgreen et al., 2012; Keränen and Jalkala, 2013). This is probably due to the subjective nature of the concept of customer value (Vargo and Lusch, 2008) and because, often, value creation is realized only after a long period of time (Tuli et al., 2007). In addition, the current study responds to calls to test for nomological validity (Ulaga and Eggert, 2006a; 2006b) by examining the links between relationship value and relationship marketing outcomes. The study confirms that 
relationship value suggests a strong antecedent of relationship effectiveness and proposes that relationship value should be included when building relationship models.

From a methodological perspective, the current study attempts a 'close' replication of the Ulaga and Eggert (2006a) work, using the same research instrument in a comparable context to test for the robustness of the proposed model of relationship value (Hubbard and Armstrong, 1994). Also, considering that the findings can be viewed within the "boundary conditions", the realistic setting where statistical effect occurs (Babin et al., 2016), replicating the Ulaga and Eggert (2006a) study in a similar context provides further assurance of the generalizability (Hubbard and Lindsay, 2013) and practical relevance (Yang and Lynn, 2014) of the results of the original study. In addition, the study extends the original study and increases its application beyond merely the existing conceptualisation. Our empirical method enabled us to compare and contrast the results of the extension of Ulaga and Eggert (2006a) in a rigorous fashion. While the primary method, SEM, allowed us to test the effect of the relationship value on the outcomes of customer loyalty and customer business performance, a secondary analysis using fsQCA supported our initial results.

From a managerial perspective this study offers insights for managers on how to assess which value drivers suggest a stronger base for differentiation in business relationships. In other words, which value drivers are key and which are not-so-important to achieve successful customer relationships and differentiate in the market. This is important for firms when developing relationship strategies for improved performance and/or cost savings.

The remainder of the paper is organized as follows. First, the theoretical background of the study is presented. Then, the research model and research hypotheses are developed. The methodological approach of the study follows. The analysis of the data and the testing of the hypotheses are then presented. The final sections present the discussion and implications of the research findings, the limitations of the study and suggestions for future research. 


\section{Literature review}

\subsection{Relationship value in business markets}

The concept of customer value is increasingly seen as a source of competitive advantage (Kumar and Reinartz, 2016; Woodruff, 1997). In business markets, in particular, customer value is argued to be the cornerstone of marketing management process due to the predominant role that functionality or performance plays in business markets (Anderson et al., 2009). Even though customer value in business-to-business markets has been conceptualized under different perspectives (for a review, see Sullivan et al., 2012) prior research has identified a number of key characteristics. Specifically, customer value is subjective, based on customers' perceptions of value rather than what the firm objectively determines as 'value' in a certain product/service offering (Payne et al., 2017; Vargo and Lusch, 2008). Value creation is not limited to single transactions but also involves all benefits acquired and costs incurred by customers during their collaboration with a supplier (Ritter and Walter, 2012; Grisaffe and Kumar, 1998). In addition, value perceptions are relative to competition (Gale, 1994). In brief, customer value can be generally defined as the trade-off between the benefits ('what you get') and the sacrifices ('what you give') in an exchange (Zeithaml, 1988; Ulaga and Eggert, 2006a, 2006b).

Following these findings about what customer value involves and focusing on its implications for relationship marketing, Payne and Holt (1999) argued for the need to consider customer value from the viewpoint of relationship marketing. This approach is described as 'relationship value'. There has been an increasing interest in conceptualizing and measuring the value of buyer-seller relationships in business markets over the years (Lindgreen at al., 2012; Biggemann and Buttle, 2012; Ravald and Grönroos, 1996; Lapierre, 2000; Sánchez-Gutiérrez et al., 2019; Anderson and Narus, 1998; Walter et al., 2001; Ulaga, 
2003; 2011; Ulaga and Eggert, 2005; 2006a; 2006b). The central idea in this research has been that the economic consequences of relationships (benefits and costs) can be driven by relational aspects that go beyond traditional product/service transactions, such as personal interaction and communication flows (Corsaro and Snehota, 2010). In other words, the value of a relationship is more relation-specific than transaction-specific (Corsaro and Snehota, 2010; Hakansson, 1982; Gadde and Snehota, 2000).

The concept of relationship value is exemplified by the works of Ulaga (2003) and Ulaga and Eggert $(2005 ; 2006 a)$, who have suggested that relationship value in a business relationship is a multidimensional construct that goes beyond the price vs. quality trade-off. Although the literature provides no consensus on a single definition of relationship value (Baxter, 2009), there is general agreement that relationship value is distinct from product value (Grönroos, 2011; Ravald and Grönroos, 1996; Ulaga and Eggert, 2006a; Wagner et al., 2010; Corsaro and Snehota, 2010). While product value focuses on the exchange object and the practical utility of an offering, relationship value focuses on the additional benefits and sacrifices arising from the interaction between the two parties that are beyond product-related issues. Our understanding of customer value in business markets has evolved from objects of exchange towards a more complicated, holistic view of interactions (Grönroos and Helle, 2012; Lindgreen et al., 2012). This is also noted in the more managerial literature, where studies have pointed out that business-to-business firms, due to the complexity of their total offering, require specific processes and tools to assess and communicate the value created for customers (e.g. Oström et al., 2010; Ulaga and Reinartz, 2011). In this context, relationship value has emerged as a particularly relevant paradigm to understand better the value of buyer-seller relationships in business markets (Biggemann and Buttle, 2012; Corsaro and Snehota, 2010; Lefaix-Durand et al., 2009). 
Different perspectives on relationship value have been proposed in the literature, capturing a wide range of factors, both 'tangible' (e.g. economic or utility-related factors) and 'intangible' (e.g. factors related to strategic, social or behavioural value) (c.f. Anderson et al. 1993; Wilson and Jantrania 1994; Walter et al., 2001; Baxter and Matear, 2004; Biggemann and Buttle, 2012). The most comprehensive, to the best of our knowledge, attempt to conceptualize and operationalize the construct of relationship value in business markets is the work of Ulaga and Eggert (2006a), which suggests the focus of this study. Ulaga and Eggert (2006a) classify the relationship benefits and costs across the three levels on which these drivers operate (i.e., the core offering, the sourcing process and the customer firm's internal operations).

The previous discussion illustrates the meaning of the relationship value in business markets and the complexity of its assessment. Despite its relevance, however, very few studies have attempted to operationalize relationship value based on a psychometrically sound methodology (Barry and Terry, 2008; Biggemann and Buttle, 2012). There is therefore need for research that reveals the construct's nomological structure along with its outcomes (Ulaga and Eggert, 2006b; Barry and Terry, 2008; Macdonald et al., 2016; Santos et al., 2018). Moreover, due to the subjective nature of the concept of value (Vargo and Lusch, 2008), more research is needed about how value is created over time in business relationships (Munksgaard and Frandsen, 2019). This is particularly important nowadays as customer perceptions and assessment of value drivers can also change by the evolution of the business environment that alter the levels and way of communication and cooperation in business relationships (Salo, 2017). Firms should adapt their marketing strategy and reallocate their marketing investments during recessionary periods. Empirical studies from previous recessions suggest that companies who continue their marketing efforts during a recession will see significant benefits, yet the majority of firms respond a recession by either cutting or 
reallocating their marketing investments (Srinivasan et al., 2005; Gulati et al., 2010). This reallocation includes a better integration between sales and marketing functions and the shift from traditional marketing to online marketing, including a rise in the social media from business-to-business firms (Rollins et al., 2014). The business environment seems to have substantially changed since the Ulaga and Eggert (2006a) study. The business-to-business exchanges are characterized by an increasing role of digitalization and an increased complexity, which can affect the nature and relative importance of the value drivers in business markets. There are therefore calls for more complex types of empirical investigation such as longitudinal and replication studies that provide more confidence on the aspects of relationship value that have emerged from previous studies (Ulaga and Eggert, 2006a; Wagner et al., 2010; Biggemann and Buttle, 2012). Motivated by and building on the above research and the recent thinking on relationship value assessment, the intent of this study is to replicate the Ulaga and Eggert (2006a) conceptualization of relationship value and explicate the linkages between relationship value and firm customer-focused performance outcomes. In the following section we present the hypotheses of the study.

\subsection{Hypotheses and research model}

Ulaga and Eggert (2006a) used empirical data from a study among purchasing managers of US manufacturing firms and proposed two main hypotheses, which we adapt to a similar research context in the UK. Ulaga and Eggert (2006a) hypothesized that relationship value can be operationalized as a higher-order formative construct and proposed a number of value drivers that serve as key differentiators in business markets. Ulaga and Eggert (2006a) found support for these hypotheses. We also extend Ulaga and Eggert's (2006a) work by examining the effect that relationship value has on customer loyalty and customers' business performance (see Figure 1). 


\subsubsection{Replicated Hypotheses}

The concept of relationship value is exemplified by the works of Ulaga (2003) and Ulaga and Eggert (2005; 2006a), who have suggested that the relationship value in a business relationship is a multidimensional, second-order construct including dimensions of benefits and costs that reach beyond a trade-off between quality and price.

Drawing on Cannon and Homburg (2001), who recognized that reducing costs in exchange is a key source for creating value in business relationships, Ulaga and Eggert (2006a), in their seminal work, proposed a differentiation between benefits and costs as key drivers of value creation, as well as three levels at which these drivers operate (i.e., the core offering, the sourcing process, and the customer firm's internal operations). Key drivers of relationship value in business markets have emerged as the dimensions of product quality, delivery performance and direct product costs at the level of a supplier's core offering; service support, personal interaction and acquisition costs in the sourcing process; and supplier know-how, time to market and operations costs at the level of the customer's operations.

The literature provides no consensus on whether relationship value should be modelled using reflective or formative measures (for a review, see Baxter, 2009). Based on the results of their grounded theory study, Ulaga and Eggert (2006a) adopted a formative measurement approach. Ulaga and Eggert (2006a) considered this approach more appropriate as the dimensions are assumed to cause the higher-order constructs (not being caused by them, as the reflective models approach suggests), having little correlation between them. Indeed, a supplier may excel on product quality but score low on delivery performance. Specifically, Ulaga and Eggert (2006a) propose a formative third-order measurement model of relationship value which has two second-order drivers, relationship benefits and relationship sacrifices. In turn, each of these second-orders drivers is defined by several first-order drivers. Relationship 
benefits have three first-order drivers, named core benefits (formed by product quality and delivery performance), sourcing benefits (formed by service support and personal interaction), and operations benefits (formed by supplier know-how and time to market). Relationship costs have three first-order drivers, named as direct product costs, acquisition costs and operations costs.

Building on the above, Ulaga and Eggert (2006a) examine two main hypotheses regarding the measurement and dimensions of relationship value, which we adapt to our context as follows:

H1: Relationship value is operationalized as a higher-order formative construct

H2: The proposed value drivers (i.e. two key dimensions of value creation benefits and costs - operating at three levels - core offering, sourcing and internal operations) serve as key differentiators in business markets

\subsubsection{Additional Hypotheses}

In addition to retesting Ulaga and Eggert's (2006a) hypotheses, we attempt to extend their study by testing the impact of relationship value on the relationship marketing outcomes of customer loyalty and customers' business performance. Central to Ulaga and Eggert's (2006a) reasoning, buyer-seller relationships are embedded in complex networks of relationships and hence relationship value should be examined within the network of relationship marketing. Building from this, the extension to Ulaga and Eggert (2006) provides more research directed to the embedded context within which dyadic business relationships take place, a research direction that adds to our understanding of the construct of relationship value. Much of the previous research has provided evidence that relationship value is an antecedent to loyalty and performance in business markets (e.g. Wagner and Benoit, 2015; Ulaga and Eggert, 2006b; Wagner et al., 2010; Casidy and Nyadzayo, 2019; Olaru, Purchase, 
and Peterson, 2008; Song et al., 2012; Lam et al., 2004). However, these studies, mainly for efficiency reasons, typically operationalize relationship value as a unidimensional construct. This approach, even though methodologically sound, fails to sufficiently incorporate a holistic, multi-dimensional conceptualization of relationship value in models of business relationships. Considering this gap in the literature, Ulaga and Eggert (2006a) called for more research into integrating value into the nomological network of relationship marketing. This is therefore an area which lacks empirical investigation. In line with the Ulaga and Eggert (2006a) central idea of differentiation in the market through relationship value development, the testing of whether relationship value relates to loyalty and performance provides further evidence of the nomological validity of the original scale and adds to the discussion of which performance outcomes are most influenced by customer relationships. On a more general level, the testing of this additional hypotheses will add to the generalization of the proposed relationship value within the context of relationship marketing in business markets (Hunt, 1991) and further develop relationship value as a marketing discipline. Therefore:

H3: Relationship value has a positive effect on customer loyalty

H4: Relationship value has a positive effect on customers' business performance

\section{Method}

\subsection{Design}

Data were collected by means of a structured questionnaire distributed to purchasing managers in UK manufacturing firms. A random sample of 1000 companies was obtained from a commercial list provider, ranging from small enterprises to multibillion companies. The sample consisted of firms in a large variety of industries, such as machinery and equipment, chemicals, metal products, food, mineral products, plastic products and electrical equipment. Consistently with Ulaga and Eggert (2006a), this study focuses on senior-level 
managers. A cover letter and questionnaire were sent to the head of the purchasing unit. The cover letter and survey directions indicated that the survey should be answered by a "VP/Director/Purchasing manager" or be forwarded to someone familiar with how the firm's purchasing decisions were made. The respondents were asked to compare their main supplier with the second supplier. Firms not responding after three weeks were mailed a follow-up letter and another questionnaire. A total of 228 completed and usable questionnaires were returned, a $23 \%$ response rate. Early and late respondents were compared to assess nonresponse bias via a t-test of difference in means (Armstrong and Overton, 1977). No differences were found between the two groups, suggesting that non-response bias was not a problem in our study. Table 1 presents the description of our sample.

Concerning the survey instrument, Ulaga and Eggert's (2006a) items were used to measure relationship value. To test the additional relationships proposed by this study, two further constructs were specified: expectation of continuity, which captures loyalty, and customers' business performance (relative to competitors). Appendices A and B list the items used in the survey. Face validity was refined by asking five academics and five practitioners to assign items to constructs.

\section{TABLE 1 AROUND HERE}

The statistical methods used to test our hypotheses were structural equation modeling (SEM) and fuzzy-set Qualitative Comparative Analysis (fsQCA). SEM using the Amos software program was used to offer insights into the net effects at both the replication and extension phase of the study. Subsequently, to check the results and consider other possible paths for relationship value dimensions to relate to performance outcomes, the data were again analyzed using fsQCA (Ragin, 2008). The aim was to compare and contrast the SEM results with those of fsQCA. 
FsQCA differs from regression-based statistical techniques in important ways. First, fsQCA allows the assessment of asymmetrical relationships among causal conditions. Second, fsQCA admits equifinality, which means that multiple paths or solutions may produce the same outcome. Third, fsQCA embraces causal complexity, which means that not all conditions must be present for the outcome to occur; different combinations of causal conditions may lead to the same outcome. While SEM, as a correlational method, analyses symmetrical relationships between antecedents and outcomes, the focus of fsQCA is on connections expressed in terms of necessity and sufficiency (Ragin, 2008; Woodside, 2013).

\subsection{Measures properties}

The psychometric attributes of the relationship value construct were compared to the Ulaga and Eggert (2006a) study. First, consistently with Ulaga and Eggert (2006a), this study conceptualizes relationship value as a higher-order formative construct rather than a reflective construct. Following Jarvis et al.'s (2003) and Diamantopoulos et al.'s (2008) recommendations for specifying second-order formative factor models, we used a composite latent construct of relationship value and assumed the higher-order construct as a composite of its dimensions (i.e., formative first-order, formative second-order model). The items of relationship benefits were submitted to confirmatory factor analysis using Amos to assess the unidimensionality of each item to its first-order dimensions of core benefits, the sourcing process and customer operations, which Ulaga and Eggert (2006a) identified. All formative indicators exhibited reliability (Cronbach's alpha >.7) (Nunnally, 1978). The average variance extracted by each measure exceeds .5 , which demonstrates convergent validity (Fornell and Larcker, 1981). Discriminant validity was also established, since the average variance extracted by each construct is higher than the squared correlation between that construct and all other constructs in the study (Fornell and Larcker, 1981). Having 
established the reliability and validity of the measures, summated scales were created for the benefit dimensions (measure properties are available on request).

Consistently with Ulaga and Eggert (2006a), relationship costs were assessed based on three formative dimensions: direct product costs, acquisition costs and operations costs, following Cannon and Homburg's (2001) classification. Summated scales were created for the respective cost dimensions.

To achieve identification with formative indicator models, the study constrained the path in each formative construct to one and included two reflective indicators for relationship benefits (RB1, RB2), as well as two reflective indicators for relationship costs (RC1, RC2) (Jarvis et al., 2003). Following Jarvis et al. 's (2003) recommendations for choosing reflective indicators for identification, items were chosen that captured consumers' overall evaluation of the formative constructs of relationship benefits and costs.

\subsection{Replication considerations}

Lindsay and Ehrenberg (1993) argue that with "close replication" differences between two studies are not expected to produce different results; with "differentiated replication" differences are expected to affect the data in a different way from the original replicated study. Given that, to the best of our knowledge, the Ulaga and Eggert (2006a) work has not been replicated specifically in any context, this study first attempts a close replication using a rather similar context and methodology.

In particular, as in Ulaga and Eggert's (2006a) research, the sample for this study involves manufacturing firms, as they appear to be prone to relationship value dimensions. In addition, the inclusion of other sectors could impose problems in evaluating our findings in relation to Ulaga and Eggert's (2006a). Furthermore, similarly to Ulaga and Eggert (2006a), a mail survey was implemented and senior-level managers were selected as key informants. 
This research therefore provides a strong basis to compare and contrast with Ulaga and Eggert's (2006a) study.

Also, it is important to note one key procedural difference between our study and Ulaga and Eggert's (2006a): the respondents of this study were marketing executives working in the UK, whereas Ulaga and Eggert's (2006a) were working in the US. Previous studies (Grayson and Ambler, 1999) have shown that there are strong similarities between the UK and US in the factors that drive buyer-seller relationships. It can therefore be anticipated that the differences in respondent nationality would not encourage significantly different results from those found by Ulaga and Eggert (2006a). Moreover, in cases when there are differences in the methodology but similar results emerge, this provides stronger evidence of theory generalizability (Farley, Lehmann, and Mann, 1998). It can be argued therefore that the difference in the empirical context between this study and Ulaga and Eggert (2006a) can provide a basis for contribution in the area of relationship value assessment.

\section{Results}

Once the requirements for the use of the higher-order formative value constructs were satisfied, the structural model in Figure 1 was tested. We used SEM by means of Amos for the analysis of the data. The results match Ulaga and Eggert's (2006a) in that all loadings were significant $(\mathrm{p}<.05)$, and each item loaded significantly on its respective underlying concept. The results indicate acceptable fit indexes, particularly given the attenuation in fit measures for large models such as the one tested here: $\mathrm{x}^{2}(71)=213.8, \mathrm{p}<.01$; comparative fit index $=.98 ;$ goodness-of-fit index $=.96$; and root mean square error of approximation $=.07$. Also, the model explains $85.2 \%$ of the variance of the value construct, indicating the predictive validity of the value dimensions. Therefore, the findings provide support for Ulaga 
and Eggert's (2006a) measurement of relationship value as a higher-order formative construct, supporting $\mathrm{H} 1$.

\section{FIGURE 1 AROUND HERE}

Next, each value dimension's relative importance for differentiation in a relationship was assessed (see Table 2). The results match Ulaga and Eggert's (2006a) in that service support and personal interaction (i.e., the sourcing process) are found as core differentiators, explaining nearly half the variance $(44 \%)$. The second more important set of differentiators comprises supplier know-how and its ability to improve a customer's time to market (i.e. operation benefits), which explains $28 \%$ of the variance. Product quality and delivery performance (i.e., core benefits) display a relatively moderate potential for differentiation, explaining $19 \%$ of the variance. Acquisition costs (4\% of the variance), operations costs (3\% of the variance) and direct costs (2\% of the variance) display a weak potential for differentiation. The results therefore provide support for H2. Consistently with Ulaga and Eggert (2006a), the results indicate that relationship benefits are more important than relationship costs. The results show that benefits, in total, explain nearly $91 \%$ of the variance, whereas costs account for just less than $9 \%$. To some extent this finding differs from Ulaga and Eggert's (2006a), who found that relationship benefits are nearly four times more important than costs (i.e., the explained variance was $81 \%$ and $20 \%$ respectively), and is contrary to the purchasing literature, which has traditionally emphasized the critical role of cost factors (price and price changes) in the selection of product offerings.

\section{TABLE 2 AROUND HERE}

To extend Ulaga and Eggert's (2006a) study, the impact of value dimensions on relationship marketing outcomes was tested (see Table 3). We used SEM by means of Amos to test these hypotheses The results show that the sourcing process $(\beta=.44, p<.01)$ and 
operations costs $(\beta=-.22, p<.01)$ affect customer loyalty (expectation of continuity), providing partial support for H3. Also, operations benefits $(\beta=.34, p<.01)$ and direct costs $(\beta=-.17, p<.01)$ influence business performance, thus partially supporting $\mathrm{H} 4$. The results indicate that value relates significantly to relationship marketing outcomes and, thus, provide evidence of the nomological validity of the construct.

\section{TABLE 3 AROUND HERE}

In next, we examine the effect of relationship value on relationship marketing outcomes using fsQCA. fsQCA describes each case as a combination of causal conditions and an outcome. The causal conditions are the relationship value dimensions that potentially lead to the outcome. In our analysis, two outcome conditions were tested: customer loyalty and customers' business performance. The causal conditions and the outcomes should be represented by a single item, which were calculated using the arithmetic mean. fsQCA builds on the premise that relationships among variables are best understood in terms of set membership and set relations (Fiss, 2011). To assess the set relations, causal conditions and outcomes have to be represented in terms of set membership scores, which requires calibration of fuzzy sets. Variables are calibrated into sets using fsQCA software. Following Ragin's (2008) recommendations, we transformed the variables into calibrated sets using three substantively meaningful thresholds: full membership (1), full non-membership (0), and a crossover point (.5). For the calibration of factors that were measured on seven-point Likert-type scales, the scale maximum (i.e., value 7) served as the threshold for full set membership and the scale minimum (i.e., value 1) was the threshold for full set nonmembership. The scale midpoint (i.e., value 4) served as the crossover point.

Following calibration, fsQCA explores how membership of cases to causal conditions is linked to membership to the outcome (Ragin 2008). FsQCA thus identifies necessary and sufficient causal conditions for the outcome to occur. A causal condition is sufficient if, by 
itself, it produces the outcome, whereas it is necessary if that condition must be present for the outcome to occur (Ragin 2000; 2008).

Table 4 shows the complex solutions that illustrate the alternative sufficient conditions that lead to high membership in each of the two outcome conditions (customer loyalty and customers' business performance). These solutions met the minimum overall consistency and overall coverage criteria that are suggested in the literature $(0.60$ for coverage and 0.75 for consistency when analyzing sufficient conditions) (Ragin 2000). Table 4 shows that both models (solutions) are informative because all consistency scores of the particular configurations range between 0.85 to 0.89 and all coverage values range between 0.48 and 0.56 , consistent with recommendations from previous research (e.g. Ragin, 2000; 2008; Fiss, 2011; Woodside, 2013).

\section{TABLE 4 AROUND HERE}

The model regarding the antecedent complex conditions that lead to loyalty derives two pathways. The first indicates that high sourcing process, with low operations costs and low direct costs results in loyalty (consistency $=0.85$; coverage $=0.48$ ), while the second pathway indicates that high sourcing process, with high operational benefits and low operations costs, also leads to loyalty. The second pathway is more consistent than the first and explains the most cases of loyalty (consistency $=0.89$; coverage $=0.53$ ). The results indicate that sourcing process and operations costs, which appear in all pathways, are the only simple antecedent conditions that are necessary (though not sufficient) for customer loyalty.

The derived solution for the antecedent conditions that lead to high customer's business performance indicates one pathway. This pathway suggests that high operations benefits with low direct costs results in high business performance. The solution is fairly 
consistent at 0.87 and has a relatively high coverage of 0.56 . Thus, these two antecedent conditions are necessary and their combination is sufficient for business performance.

The fsQCA results support the results of the net effects. These four value drivers (sourcing process, operations costs, operations benefits and direct costs) were also found to have significant effects on the relationship marketing outcomes in the SEM analysis and, thus, the results provide partial support for $\mathrm{H} 3$ and $\mathrm{H} 4$.

\section{Discussion}

Our findings must be evaluated within the context and the scope of the study. In particular, the current study focuses on Ulaga and Eggert's (2006a) work, rather than drawing on a more complete body of research on customer value in business markets. For example, studies published since Ulaga and Eggert's (2006a) work have argued that value in buyer-seller relationships can be viewed in the wider stakeholder and network context rather than just within the buyer-seller dyad (e.g. Frow and Payne, 2011). Also, other studies view customer value in terms of the solutions created and the extent to which the supplier assists customers in their own business processes, rather than delivering individual elements of value creation (e.g. products and services) (Keränen and Jalkala, 2013; Prior, 2013). Relationship value can therefore be conceptualised differently from how Ulaga and Eggert (2006a) did or additional dimensions can be considered. Even though we recognize the value of integrating a number of customer value perspectives into one single study, the purpose of this study was to replicate a seminal study whose findings go beyond the 'price vs. quality trade-off' approach of customer value and provide further confidence for these findings.

The results largely support the relationships proposed in the conceptual framework. Specifically, the findings of the replication study provide support for Ulaga and Eggert's (2006a) conceptualization of relationship value as a higher-order construct that consolidates a 
number of relationship benefits and relationship costs spanning the three levels on which these drivers operate: product quality, delivery performance and direct product costs at the level of a supplier's core offering; service support, personal interaction and acquisition costs in the sourcing process; and supplier know-how, time to market and operations costs at the level of the customer's operations. Also, both Ulaga and Eggert's (2006a) and our replication study found service support and personal interaction (i.e., sourcing process) to be core differentiators, explaining nearly half the variance (44\%), followed by supplier know-how and its ability to improve a customer's time to market (i.e. operation benefits), which explains $28 \%$ of the variance. This may be explained by the increased importance of supplier reliability and service quality, especially as business markets are often mature and product differentiation becomes more difficult. Interestingly enough, product quality and delivery performance (i.e., core benefits) are found to explain 19\% of the variance, displaying a rather moderate potential for differentiation. This is in line with more recent thinking around value creation in business markets, which argues that, instead of product bundles, customers tend to perceive value in solutions that integrate products and services into a functioning whole and the relational processes that improve customer operations (Tuli et al., 2007). Core benefits therefore appear to be a less important source of differentiation compared to aspects that touch upon the sourcing process and operation benefits.

Ulaga and Eggert (2006a) and our replication support the idea that relationship benefits are more important than relationship costs, a finding that seems to run counter to the argument that cost reduction is the main source of value in business relationships (Cannon and Homburg, 2001). Even though Ulaga and Eggert (2006a) and our replication agree on the central finding that relationship benefits are more important than relationship costs, the results show a discrepancy between the 'benefits vs. cost' scores, which suggests one difference between the two studies. In particular, our replication found that relationship 
benefits are nearly ten times more important than costs (i.e., the explained variances were $91 \%$ and 9\% respectively), whereas Ulaga and Eggert (2006a) found that relationship benefits are nearly four times more important than costs (i.e., the explained variances were $81 \%$ and $20 \%$ respectively). The difference in the results indicates that we must be cautious before generalizing this finding, as it could be context specific. A comparison of the key findings between the Ulaga and Eggert (2006a) and the current study and their implications is summarized in Table 5.

\section{TABLE 5 AROUND HERE}

The findings of the study can also be seen in the context of power in business relationships. More recent thinking in the area of value creation in business relationships (c.f. Lindgreen et al., 2012) argues that due to the changing business environment (e.g. concentration of the market in a few and important suppliers and customers, internalization of firms, difficulty to differentiate, increasing need for customer retention) some firms tend to understand better how value perceptions are formed, develop the required capabilities to compete and strengthen their position in the market. As a result, most business exchanges are power-imbalanced and the powerful party/parties seek a disproportionate share of the surplus value from the relationship, which, in turn affects the approach for increasing the value of the relationship (Hingley, 2005). Given that the current study is based on data gathered from suppliers that successfully made their way to the top of the supply base (in other words, the 'winners'), the findings of the study can provide a best-practice profile for companies striving for key supplier status. In such a context, suppliers create value for customers by focusing mainly on service support and personal interaction (i.e., sourcing process) and this can be viewed as a benchmark for firms that want to gain or maintain key supplier status. Important to note that power is not always a negative force and weaker/ secondary suppliers can also find their place in the market (Hingley, 2005; Ulaga and Eggert, 2006a). Although the 
examination of secondary suppliers goes beyond the scope of this research, the study indicates that secondary suppliers may see power trade-off as sacrifice for reduced transaction costs derived from regular business with a more powerful party and regular (although as weaker party, lesser) returns derived from relationship value. A secondary supplier may develop a unique expertise and provide selected customers with a better solution for a reduced fee in exchange for an incremental share of a customer's business. Although relationship benefits display stronger potential for differentiation in buyer-seller relationships than cost considerations, the study indicate that the main drivers of the relationship value can change according to the changes of business environment and the consequent differences in the negotiation power each party may have.

In line with the above discussion, the way customers perceive and interpret value can also be seen in light of the digital dimension of business interaction and the increasing use of social media from business-to-business companies. Recent studies show that social media affect the levels of communication and information exchange in business relationships and alter the level of cooperation and adaptations leading to enhanced customer relationships (Salo, 2017; Andersson and Wikström, 2017). The immediacy of social networks supports relationships that may otherwise be slow to connect, as new contacts are easier to make and the amount of screening is being reduced comparing to traditional relationships (Quinton and Wilson, 2016). Overall, buyer-seller relationships can be improved with the communication mode provided by social media. The study posits that the value drivers are not static, rather they can change following the evolution of the business environment. As supplier firms and the customers are increasingly utilizing social media in the marketing and purchasing efforts to achieve their objectives from the relationships, the relative importance of the value drivers that relate to the communication, social interaction and knowledge exchange between the 
exchange parties will also increase. This is supported by the findings of the study that found service support and personal interaction (i.e., sourcing process) to be core differentiators.

Turning to the extension phase, the results show that, largely, the dimensions of relationship value relate to relationship effectiveness. The sourcing process and customer operations are found to have the greatest influence on loyalty and business performance, followed by operations costs and direct costs. This finding is interesting for three reasons. First, it considers relationship value in association with relationship marketing outcomes, thus providing further evidence of the nomological validity of the Ulaga and Eggert (2006a) scale. This finding offers insights into how relationship marketing models can better fit with managerial practice in business markets by including performance-based measures (customers' business performance) to broaden the nomological network of relationship marketing (Ulaga and Eggert, 2006b). Second, this finding indicates that different dimensions of a relationship value may be synergistic, and relationship performance may be possible only when the supplier manages to address many critical aspects. The link between relationship value and performance outcomes offers insights into the fundamental question in relationship marketing literature: what outcomes are most affected by customer relationships? (Palmatier et al., 2006). Third, even though these relationship benefits and costs influence loyalty and customers' business performance, none of the other antecedents of performance outcomes are significant. This finding is not surprising; although relational constructs are important drivers of customer-focused outcomes of a relationship (Palmatier et al., 2006; Palmatier, 2008), they cannot fully explain their variance. Loyalty and, most importantly, business performance, may also be determined by other, non-relational factors (e.g., competition, the economy).

The fsQCA results support the SEM results. The results reveal that neither sourcing process nor operations costs (as well as other value drivers) are sufficient conditions for loyalty. However, the results show that high sourcing process and low operations costs are 
necessary conditions for loyalty. The results also show that the influence of operations benefits and direct costs on customer's business performance is conditional and depends on the combination of specific antecedent conditions (i.e. causal recipes). More specifically, relationship value may lead to customer's business performance when the supplier provides high operations benefits and low direct costs at the same time. These findings correspond to the results of the net effects (SEM) analysis, which indicate that sourcing process and operations costs have a significant effect on loyalty and customer operations and direct costs have significant effects on business performance.

\section{Implications}

The findings of this replication study have several implications for research and practice. From a theoretical perspective, the study supports the notion that relationship value in business markets is not merely a theoretical construct viewed on a high level of abstraction, but rather it can also be empirically measured. This is important because researchers in this area have found difficulties when it comes down to the empirical assessment of relationship value. Also, the findings that distinct elements of value influence 'loyalty' (an expectation of continuity) while other elements influence business performance (relative to competitors) are very interesting and deserve attention. Specifically, the sourcing process and operations costs affect loyalty, while customer operations and direct costs influence business performance. This indicates (given the influence of the sourcing process on relationship value) that value is more strongly connected to loyalty than to business performance. In addition to this, the findings provide evidence that business performance is mainly related to more objective aspects of value, whereas loyalty relates to more subjective aspects.

On a more general level, the paper is in line with an emerging discussion that challenges the traditional practices of writing and disseminating marketing research where 
'originality' emerges as a self-serving objective and as the main way to advance marketing research (c.f. Hubbard and Lindsay, 2013; Babin et al., 2016; Ortinau, 2011; Armstrong, 2003). We recognise that there is increasing pressure for marketing academics, especially early career researchers, to provide evidence that their scholarly work is innovative and breakthrough even (Armstrong, 2003; Ortinau, 2011; Ladik and Stewart, 2008) to publish in highly-ranked journals (Woodside, 2009). However, the contribution of a piece of research should not depend only on the originality of the work (e.g. the proposition of new, differentiated conceptual frameworks or new hypotheses). The replication of previous studies can also be key to theory development (Tsang and Kwan, 1999) and to the generalizability of findings (Hubbard and Lindsay, 2013). This is particularly important in the area of value creation in business markets, where many divergent models have been proposed but the assessment of relationship value still remains a challenge for both academics and researchers. A key question therefore is: do we really need a new, 'original' model or can the replication of an important framework lead to more meaningful and generalizable results and, thus, advance our knowledge of marketing phenomena? The present study argues that although the effort of fostering the development of new knowledge should not be diminished - this is an exercise that should always govern the academic community - the replication of important, though insufficiently tested for their robustness, findings is also key to theory development. The Ulaga and Eggert (2006a) calls for such an approach and in this respect the present study adds to existing knowledge.

Moreover, and from a methodological point of view, this research shows how fsQCA can complement findings of conventional, correlation-based statistical procedures such as regression and structural equation modelling (SEM) to obtain more nuanced insights into phenomena of interest where complex causality is likely, such as relationship value. Studies indicate that relationship characteristics often relate to each other (interdependence), that the 
relational outcomes seldom have a single cause (multi-causality), and that a specific cause may have different (i.e., positive and negative) effects depending on context (asymmetry) (e.g. Palmatier et al., 2006; Grayson and Ambler, 1999; Song et al., 2016). In line with previous studies (e.g. Paulssen et al., 2016; Cruz-Ros et al., 2018), this study demonstrates that fsQCA is a relevant analytical tool that can be used in conjunction with other correlation-based statistical procedures such as SEM to deepen the understanding of value creation in business markets and provide researchers and managers with more accurate diagnostics.

The study has also important managerial implications. The findings provide guidelines regarding each value driver's potential for differentiating among suppliers. Which value drivers are key when seeking to differentiate among suppliers in business relationships? Which dimensions show only a limited potential for differentiation? In turn, from a customer perspective, which dimensions help discriminate among competing suppliers and further consolidate a supply base? The study provides a useful self-diagnostic tool to track whether they meet customers' needs and to identify areas where further improvement is needed.

Also, from a managerial perspective, understanding how specific dimensions relate to value creation can help suppliers enhance relationship effectiveness through initiatives involving those factors. The findings show that customers seem more concerned about relationship benefits than cost considerations. The study argues that although internal cost reduction, which can ultimately lead to price reduction, should not be ignored, suppliers should focus on creating value through personal interaction, service quality, product enhancements and delivery efficiency. Cost competitiveness is a necessary but not sufficient condition to differentiate in business markets. In other words, relationship benefits are more important than relationship costs when it comes to choosing the main supplier from a short list of potential suppliers. To get on the short list, price (and quality) are still of major importance. 
Finally, the findings suggest by focusing on relationship building and service excellence firms can create value for the inter-organizational relationships. This highlights the importance of relational capabilities for both buyers and sellers, as they manage relations with their business partners. Relational capabilities capture the internal attributes of a firm that shape the performance of joint activities with exchange partners (Kale and Singh, 2007). They are largely embedded in organizational routines, which are repetitive activities that a firm develops to deploy resources more effectively (Heimeriks and Duysters, 2007). The increasing complexity of the business relationships due to the changing business environment and the need to coordinate complementary resources increases the level of interdependence between firms and, as a result, the relationship requirements change (Ngugi et al., 2010). The development of relational capabilities such as knowledge sharing, technological capability, human capability, managerial systems-based capability, and cultural interaction capability are important for both suppliers and buyers to enhance partnership performance and hence can increase the value of the relationship (Johnsen and Ford, 2006; Rungsithong et al., 2017). At an operational level, and as the findings in Figure 1 indicate, relationship value can be enhanced by personal interaction and knowledge sharing routines and managerial systemsbased capability to ensure delivery efficiency. These relational capabilities may be embedded in specific units of the organizations, such as the marketing, sales or purchasing department or can also involve the formation of interdependent teams.

\section{Limitations and future research}

The study has some limitations that offer opportunities for future research. First, data for this research are based on the customer's perspective of relationship value. Given that a relationship is, by its very nature, two-sided, future research using dyads as a research setting would offer a more comprehensive view of the value construct and help identify potential gaps between supplier and customer perspectives. 
Second, given the dynamic nature of the construct, future longitudinal research could offer useful insights on how value is created over time. Although this study contributes towards this direction, it remains a static assessment of relationship value.

Third, future research could further develop the proposed relationship value construct by integrating additional facets of relationships that the literature has proposed. Researchers may want to consider the inclusion of tangible aspects such as the functionality or practical utility of an offering (Anderson et al., 2006) and/or intangible aspects of customer value such as the reputation, skills, location or innovativeness of the supplier (Whitwell et al., 2007).

Finally, future research can examine the value drivers in association to recent changes in the business environment such as the adoption of digital content marketing or social media. For example, future researchers can examine how business marketers can utilise social media in their marketing efforts to enhance relationship value. Considering that social media affects information sharing, social exchange, cooperation and adaptations in business relationships (Salo, 2017; Magno and Cassia, 2019), it could be argued that the use of social media improves the connectedness between buyers and sellers, thus leading to an increase of the importance of relational-focused value drivers. Future studies should develop models that address value creation incorporating changes in the economic and business setting.

\section{References}

Anderson, J.C., Jain, D., and Chintagunta, P.K. (1993), “Understanding customer value in business markets: Methods of customer value assessment”, Journal of Business-toBusiness Marketing, Vol. 1 No. 1, pp. 3-30.

Anderson, J.C. and Narus, J.A. (1998), "Business marketing: Understand what customers value", Harvard Business Review, Vol. 76 No. 6, pp. 53-65. 
Anderson, J.C., Narus, J.A., and Narayandas, D. (2009), Business market management: Understanding, creating, and delivering value, 3rd edition. Pearson Education, Inc., Upper Saddle River. New Jersey.

Anderson, J.C., Narus, J.A., and van Rossum, W. (2006), “Customer value propositions in business markets", Harvard Business Review, Vol. 84 No. 3, pp. 90-99.

Andersson, S. and Wikström, N. (2017), "Why and how are social media used in a B2B context, and which stakeholders are involved?", Journal of Business \& Industrial Marketing, Vol. 32 No. 8, pp.1098-1108.

Armstrong, J.S. (2003), "Discovery and communication of important marketing findings: Evidence and proposals", Journal of Business Research, Vol. 56 No. 1, pp. 69-84.

Armstrong, J.S. and Overton, T.S. (1977), "Estimating nonresponse bias in mail surveys", Journal of Marketing Research, Vol. 14 No. 3, pp. 396-402.

Babin, B.J., Griffin, M., and Hair Jr, J.F. (2016), "Heresies and sacred cows in scholarly marketing publications”, Journal of Business Research, Vol. 69 No. 8, pp. 3133-3138.

Baxter, R. (2009), "Reflective and formative metrics of relationship value: A commentary essay”, Journal of Business Research, Vol. 62 No. 12, pp. 1370-1377.

Baxter, R. and Matear, S. (2004), "Measuring intangible value in business-to-business buyerseller relationships: An intellectual capital perspective”, Industrial Marketing Management, Vol. 33 No. 6, pp. 491-500.

Biggemann, S. and Buttle, F. (2012), "Intrinsic value of business-to-business relationships: An empirical taxonomy”, Journal of Business Research, Vol. 65 No. 8, pp. 1132-1138.

Cannon, J.P., and Homburg, C. (2001), "Buyer-supplier relationships and customer firm costs”, Journal of Marketing, Vol. 65 No. 1, pp. 29-43. 
Casidy, R., and Nyadzayo, M. (2019), "Drivers and outcomes of relationship quality with professional service firms: An SME owner-manager perspective", Industrial Marketing Management. Vol. 78, April, pp. 27-42.

Corsaro, D. and Snehota, I. (2010), "Searching for relationship value in business markets: are we missing something?", Industrial Marketing Management, Vol. 39 No. 6, pp. 986995.

Cruz-Ros, S., Guerrero-Sánchez, D.L. and Miquel-Romero, M.J.. (2018), “Absorptive capacity and its impact on innovation and performance: findings from SEM and fsQCA", Review of Managerial Science, pp.1-15.

Diamantopoulos, A., Riefler, P., and Roth, K.P. (2008), “Advancing formative measurement models", Journal of Business Research, Vol. 61 No. 12, pp. 1203-1218.

Farley, J.U., Lehmann, D.R. and Mann, L.H. (1998), “Designing the next study for maximum impact”, Journal of Marketing Research, Vol. 35 No. 4, pp.496-501.

Fiss, P.C. (2011), "Building better causal theories: A fuzzy set approach to typologies in organization research", Academy of Management Journal, Vol. 54 No. 2, pp. 393-420.

Fornell, C. and Larcker, D.F. (1981), "Evaluating structural equation models with unobservable variables and measurement error", Journal of Marketing Research, Vol. 18 No. 1 , pp. 39-50.

Frow, P. and Payne, A. (2011), “A stakeholder perspective of the value proposition concept", European Journal of Marketing, Vol. 45 No. 1/2, pp. 223-240.

Gadde, L.E., and Snehota, I. (2000), "Making the most of supplier relationships", Industrial Marketing Management, Vol. 29 No. 4, pp. 305-316. 
Gale, B.T. (1994), Managing customer value: Creating quality and services that customers can see, New York: Free Press.

Grayson, K., and Ambler, T. (1999), “The dark side of long-term relationships in marketing services", Journal of Marketing Research, Vol. 36 No. 1, pp. 132-141.

Grisaffe, D.B., and Kumar, A. (1998), “Antecedents and consequences of customer value: testing an expanded framework", MSI Report No. 98-107. Cambridge, MA: Marketing Science Institute

Grönroos, C. (2011), "A service perspective on business relationships: The value creation, interaction and marketing interface", Industrial Marketing Management, Vol. 40 No. 2, pp. $240-247$.

Grönroos, C. and Helle, P. (2012), "Return on relationships: conceptual understanding and measurement of mutual gains from relational business engagements", Journal of Business \& Industrial Marketing, Vol. 27 No. 5, pp. 344-359.

Gulati, R., Nohria, N., and Wohlgezogen, F. (2010), “Roaring out of recession”, Harvard Business Review, Vol. 88 No. 3, pp. 62-69.

Hakansson, H. (1982), International marketing and purchasing of industrial goods. An interaction approach, New York: John Wiley \& Sons.

Heimeriks, K.H. and Duysters, G. (2007), “Alliance capability as a mediator between experience and alliance performance: an empirical investigation into the alliance capability development process", Journal of Management Studies, Vol. 44 No. 1, pp. 25-49.

Hingley, M. K. (2005), "Power to all our friends? Living with imbalance in supplier-retailer relationships", Industrial Marketing Management, Vol. 34 No. 8, pp. 848-858. 
Hubbard, R. and Armstrong, J.S. (1994), "Replications and extensions in marketing: Rarely published but quite contrary", International Journal of Research in Marketing, Vol. 11 No. 3, pp. 233-248.

Hubbard, R. and Lindsay, R.M. (2013), "From significant difference to significant sameness: Proposing a paradigm shift in business research", Journal of Business Research, Vol. 66 No. 9, pp. 1377-1388.

Hunt, S. D. (1991), Modern marketing theory: Critical issues in the philosophy of marketing science, South-Western Publishing Company, Cincinnati, $\mathrm{OH}$.

Jarvis, C.B., MacKenzie, S.B., and Podsakoff, P.M. (2003), “A critical review of construct indicators and measurement model misspecification in marketing and consumer research", Journal of Consumer Research, Vol. 30 No. 2, pp. 199-218.

Johnsen, R.E. and Ford, D. (2006), "Interaction capability development of smaller suppliers in relationships with larger customers", Industrial Marketing Management, Vol. 35 No. 8, pp. 1002-15.

Kale, P. and Singh, H. (2007), "Building firm capabilities through learning: the role of the alliance learning process in alliance capability and firm-level alliance success", Strategic Management Journal, Vol. 28 No. 10, pp.981-1000.

Keränen, J. and Jalkala, A. (2013), “Towards a framework of customer value assessment in B2B markets: An exploratory study", Industrial Marketing Management, Vol. 42 No. 8, pp. 1307-1317.

Kumar, V. and Reinartz, W. (2016), "Creating enduring customer value", Journal of Marketing, Vol. 80 No. 6, pp. 36-68.

Kumar, V., Petersen, J.A., and Leone, R.P. (2013), “Defining, measuring, and managing business reference value", Journal of Marketing, Vol. 77 No. 1, pp. 68-86. 
Ladik, D.M. and Stewart, D.W. (2008), "The contribution continuum", Journal of the Academy of Marketing Science, Vol. 36 No. 2, pp. 157-165.

Lam, S.Y., Shankar, V., Erramilli, M.K., and Murthy, B. (2004), "Customer value, satisfaction, loyalty, and switching costs: An illustration from a business-to-business service context", Journal of the Academy of Marketing Science, Vol. 32 No. 3, pp. 293311.

Lapierre, J. (2000), “Customer-perceived value in industrial contexts", Journal of Business \& Industrial Marketing, Vol. 15 No. 2/3, pp. 122-145.

Lefaix-Durand, A., Kozak, R., Beauregard, R. and Poulin, D. (2009), “Extending relationship value: observations from a case study of the Canadian structural wood products industry”, Journal of Business \& Industrial Marketing, Vol. 24 No. 5/6, pp. 389-407.

Lindgreen, A., Hingley, M.K., Grant, D.B., and Morgan, R.E. (2012), "Value in business and industrial marketing: Past, present, and future”, Industrial Marketing Management, Vol. 41 No. 1, pp. 207-214.

Lindsay, R.M. and Ehrenberg, A.S. (1993), "The design of replicated studies”, The American Statistician, Vol. 47 No. 3, pp. 217-228.

Macdonald, E.K., Kleinaltenkamp, M., \& Wilson, H.N. (2016), "How business customers judge solutions: Solution quality and value in use", Journal of Marketing, Vol. 80 No. 3, pp. 96-120.

Magno, F. and Cassia, F. (2019), "Establishing thought leadership through social media in B2B settings: effects on customer relationship performance", Journal of Business \& Industrial Marketing, ahead-of-print. https://doi.org/10.1108/JBIM-12-2018-0410

Munksgaard, K.B. and Frandsen, K. (2019), “Actions for relationship value: a mission impossible?", European Journal of Marketing, Vol. 53 No. 5, pp. 892-915. 
Ngugi, I.K., Johnsen, R.E. and Erdélyi, P. (2010), "Relational capabilities for value cocreation and innovation in SMEs", Journal of Small Business and Enterprise Development, Vol. 17 No. 2, pp.260-278.

Nunnally, J.C. (1978), Psychometric Theory, 2 edition, New York, McGraw-Hill.

Olaru, D., Purchase, S. and Peterson, N. (2008), "From customer value to repurchase intentions and recommendations", Journal of Business \& Industrial Marketing, Vol. 23 No. 8, pp.554-565.

Ortinau, D.J. (2011), "Writing and publishing important scientific articles: A reviewer's perspective", Journal of Business Research, Vol. 64 No. 2, pp. 150-156.

Oström, A.L., Bitner, M.J., Brown, S.W., Burkhard, K.A., Goul, M., Smith-Daniels, V., et al. (2010), "Moving forward and making a difference: Research priorities for the science of service", Journal of Service Research, Vol. 13 No. 4, pp. 4-36.

Palmatier, R.W. (2008), "Interfirm relational drivers of customer value", Journal of Marketing, Vol. 72 No. 7, pp. 76-89.

Palmatier, R.W., Dant, R.P., Grewal, D., and Evans, K.R. (2006), "Factors influencing the effectiveness of Relationship Marketing: A meta-analysis”, Journal of Marketing, Vol. 70 No. 4, pp. 136-153.

Parasuraman, A., Berry, L.L., and Zeithaml, V.A. (1991), "Refinement and reassessment of the SERVQUAL scale”, Journal of Retailing, Vol. 67 No. 4, pp. 420-450.

Paulssen, M., Leischnig, A., Ivens, B.S. and Birk, M.M. (2016), "Relational norms in customer-company relationships: Net and configurational effects", Journal of Business Research, Vol. 69 No. 12, pp.5866-5874. 
Payne, A. and Holt, S. (1999), "A review of the 'value' literature and implications for relationship marketing”, Australasian Marketing Journal (AMJ), Vol. 7 No. 1, pp. 4151.

Payne, A., Frow, P., and Eggert, A. (2017), “The customer value proposition: evolution, development, and application in marketing", Journal of the Academy of Marketing Science, Vol. 45 No. 4, pp. 467-489.

Prior, D.D. (2013), "Supplier representative activities and customer perceived value in complex industrial solutions", Industrial Marketing Management, Vol. 42 No. 8, pp. 1192-1201.

Quinton, S. and Wilson, D. (2016), "Tensions and ties in social media networks: Towards a model of understanding business relationship development and business performance enhancement through the use of LinkedIn", Industrial Marketing Management, Vol. 54, April, pp. 15-24

Ragin, C. C. (2000), Fuzzy-set social science, Chicago: University of Chicago Press

Ragin, C. C. (2008), Redesigning social inquiry: Fuzzy sets and beyond, Chicago: University of Chicago Press.

Ravald, A. and Grönroos, C. (1996), "The value concept and relationship marketing", European Journal of Marketing, Vol. 30 No. 2, pp. 19-30.

Ritter, T. and Walter, A. (2012), "More is not always better: The impact of relationship functions on customer-perceived relationship value", Industrial Marketing Management, Vol. 41 No. 1, pp. 136-144.

Rollins, M., Nickell, D., and Ennis, J. (2014), “The impact of economic downturns on marketing”, Journal of Business Research, Vol. 67 No. 1, pp. 2727-2731. 
Rungsithong, R., Meyer, K.E. and Roath, A.S. (2017), "Relational capabilities in Thai buyersupplier relationships", Journal of Business \& Industrial Marketing, Vol. 32 No. 8, pp.1228-1244.

Salo, J. (2017), "Social media research in the industrial marketing field: Review of literature and future research directions", Industrial Marketing Management, Vol. 66, pp.115-129.

Sánchez-Gutiérrez, J., Cabanelas, P., Lampón, J.F. and González-Alvarado, T.E. (2019), "The impact on competitiveness of customer value creation through relationship capabilities and marketing innovation", Journal of Business \& Industrial Marketing, Vol. 34 No. 3, pp. 618-627.

Santos, J.N., Mota, J., and Baptista, C.S. (2018), "Understanding configurations of value creation functions in business relationships using a fuzzy-set QCA", Journal of Business Research, Vol. 89, August, pp. 429-434.

Song, H., Yu, K., Chatterjee, S. and Jia, J. (2016), "Service supply chain: strategic interaction and relationship value", Journal of Business \& Industrial Marketing, Vol. 31 No. 5, pp. 611-624.

Song, Y., Su, Q., Liu, Q. and Wang, T. (2012), “Impact of business relationship functions on relationship quality and buyer's performance", Journal of Business \& Industrial Marketing, Vol. 27 No. 4, pp. 286-298.

Srinivasan, R., Rangaswamy, A., and Lilien, G.L. (2005), “Turning adversity into advantage: does proactive marketing during a recession pay off?", International Journal of Research in Marketing, Vol. 22 No. 2, pp. 109-125.

Sullivan, U.Y., Peterson, R.M., and Krishnan, V. (2012), "Value creation and firm sales performance: The mediating roles of strategic account management and relationship perception”, Industrial Marketing Management, Vol. 41 No. 1, pp. 166-173. 
Tsang, E.W. and Kwan, K.M. (1999), "Replication and theory development in organizational science: A critical realist perspective”, Academy of Management Review, Vol. 24 No. 4, pp. 759-780.

Tuli, K.R., Kohli, A.K., and Bharadwaj, S.G. (2007), "Rethinking customer solutions: from product bundles to relational processes", Journal of Marketing, Vol. 71 No. 3, pp. 1-17.

Ulaga, W. (2003), "Capturing value creation in business relationships: A customer perspective”, Industrial Marketing Management, Vo. 32 No. 8, pp. 677-693.

Ulaga, W. (2011), “Investigating customer value in global business markets: Commentary essay", Journal of Business Research, Vol. 64 No. 8, pp. 928-930.

Ulaga, W. and Eggert, A. (2005), "Relationship value in business markets: the construct and its dimensions", Journal of Business-to-business Marketing, Vol. 12 No. 1, pp. 73-99.

Ulaga, W. and Eggert, A. (2006a), "Value-based differentiation in business relationships: Gaining and sustaining key supplier status”, Journal of Marketing, Vol. 70 No. 1, pp. 119-136.

Ulaga, W. and Eggert, A. (2006b), "Relationship value and relationship quality: Broadening the nomological network of business-to-business relationships", European Journal of Marketing, Vol. 40 No. 3/4, pp. 311-327.

Ulaga, W. and Reinartz, W.J. (2011), "Hybrid offerings: how manufacturing firms combine goods and services successfully", Journal of Marketing, Vol. 75 No. 6, pp. 5-23.

Vargo, S.L. and Lusch, R.F. (2008), "Service-dominant logic: continuing the evolution", Journal of the Academy of Marketing Science, Vol. 36 No. 1, pp. 1-10. 
Wagner, J. and Benoit, S. (2015), “Creating value in retail buyer-vendor relationships: A service-centered model”, Industrial Marketing Management, Vol. 44 No. 1, pp. 166179.

Wagner, S.M., Eggert, A., and Lindemann, E. (2010), "Creating and appropriating value in collaborative relationships", Journal of Business Research, Vol. 63 No. 8, pp. 840-848.

Walter, A., Ritter, T., and Gemünden, H.G. (2001), "Value creation in buyer-seller relationships: Theoretical considerations and empirical results from a supplier's perspective", Industrial Marketing Management, Vol. 30 No. 4, pp. 365-377.

Whitwell, G.J., Lukas, B.A., and Hill, P. (2007), "Stock analysts' assessments of the shareholder value of intangible assets", Journal of Business Research, Vol. 60 No. 1, pp. 84-90.

Wilson, D.T. and Jantrania, S. (1994), "Understanding the value of a relationship", AsiaAustralia Marketing Journal, Vol. 2 No. 1, pp. 55-66.

Woodruff, R.B. (1997), "Customer value: the next source for competitive advantage", Journal of the Academy of Marketing Science, Vol. 25 No. 2, pp. 139-153.

Woodside, A. G. (2013), “Moving beyond multiple regression analysis to algorithms: Calling for adoption of a paradigm shift from symmetric to asymmetric thinking in data analysis and crafting theory", Journal of Business Research, Vol. 66 No. 4, pp. 463-472.

Woodside, A.G. (2009), "Journal and author impact metrics: An editorial”, Journal of Business Research, Vol. 62 No. 1, pp. 1-4

Yang, S., and Lynn, M. (2014), "More evidence challenging the robustness and usefulness of the attraction effect”, Journal of Marketing Research, Vol. 51 No. 4, pp. 508-513. 
Zeithaml, V.A. (1988), “Consumer perceptions of price, quality, and value: a means-end model and synthesis of evidence", Journal of Marketing, Vol. 52 No. 3, pp. 2-22.

Appendix A: Items used for the replication

\begin{tabular}{|c|c|c|c|}
\hline Construct & Items & $\mathrm{M}$ & SD \\
\hline \multirow{6}{*}{$\begin{array}{l}\text { Product } \\
\text { support }{ }^{\mathrm{a}, \mathrm{c}}\end{array}$} & The main supplier provides us with better product quality & 5.56 & 0.88 \\
\hline & The main supplier meets our quality standards better & 5.25 & 1.09 \\
\hline & The main supplier's products are more reliable & 5.57 & 0.95 \\
\hline & We reject fewer products from the main supplier & 5.49 & 1.04 \\
\hline & The main supplier provides us with more consistent product quality over time & 5.49 & 0.92 \\
\hline & We have fewer variations in product quality with the main supplier & 5.78 & 0.87 \\
\hline \multirow[t]{3}{*}{ Deliverya, c } & The main supplier performs better in meeting delivery due dates & 5.33 & 1.28 \\
\hline & We have fewer delivery errors with the main supplier & 5.00 & 1.25 \\
\hline & $\begin{array}{l}\text { Deliveries from the main supplier are more accurate (no missing or wrong } \\
\text { parts) }\end{array}$ & 5.25 & 1.20 \\
\hline \multirow{4}{*}{$\begin{array}{l}\text { Service } \\
\text { support }{ }^{\mathrm{a}, \mathrm{d}}\end{array}$} & The main supplier provides us with better services & 5.39 & 1.18 \\
\hline & The main supplier is more available when we need information & 5.41 & 1.19 \\
\hline & The main supplier provides us with more appropriate information & 5.61 & 1.14 \\
\hline & The main supplier responds faster when we need information & 5.49 & 1.09 \\
\hline \multirow{7}{*}{$\begin{array}{l}\text { Personal } \\
\text { interaction }\end{array}$} & It is easier to work with the main supplier & 6.07 & 0.85 \\
\hline & We have a better working relationship with the main supplier & 6.00 & 0.75 \\
\hline & There is better interaction between the main supplier's people and ours & 5.60 & 1.00 \\
\hline & We interact better with the main supplier & 5.68 & 0.99 \\
\hline & We can address problems more easily with the main supplier & 6.29 & 0.78 \\
\hline & We can discuss problems more freely with the main supplier & 4.82 & 1.20 \\
\hline & $\begin{array}{l}\text { The main supplier gives us a greater feeling of being treated as an important } \\
\text { customer }\end{array}$ & 5.25 & 1.08 \\
\hline \multirow{5}{*}{$\begin{array}{l}\text { Supplier know- } \\
\text { how }{ }^{\mathrm{a}, \mathrm{e}}\end{array}$} & - (The main supplier provides us better access to his know-how) & 5.45 & 1.23 \\
\hline & The main supplier knows better how to improve our existing products & 5.24 & 1.21 \\
\hline & The main supplier performs better at presenting us with new products & 5.59 & 1.12 \\
\hline & $\begin{array}{l}\text { The main supplier knows better how to help us drive innovation in our } \\
\text { products }\end{array}$ & 5.11 & 1.29 \\
\hline & The main supplier knows better how to assist us in new product development & 5.72 & 1.31 \\
\hline \multirow{4}{*}{$\begin{array}{l}\text { Time to } \\
\text { market }^{\mathrm{a}, \mathrm{e}}\end{array}$} & The main supplier performs better in helping us improve our time to market & 5.16 & 1.09 \\
\hline & The main supplier helps us more in improving our cycle time & 5.73 & 1.01 \\
\hline & The main supplier helps us more in getting our products to market faster & 5.51 & 1.08 \\
\hline & $\begin{array}{l}\text { The main supplier performs better in helping us speed up product } \\
\text { development }\end{array}$ & 5.64 & 1.04 \\
\hline \multirow{4}{*}{$\begin{array}{l}\text { Relationship } \\
\text { value }^{\mathrm{a}} \text { - } \\
\text { unidimensional }_{\text {scale }}\end{array}$} & The main supplier adds more value to the relationship overall & 5.90 & 0.95 \\
\hline & We gain more in our relationship with the main supplier & 5.81 & 0.97 \\
\hline & The relationship with the main supplier is more valuable & 5.76 & 0.97 \\
\hline & $\begin{array}{l}\text { The main supplier creates more value for us when comparing all costs and } \\
\text { benefits in the relationship }\end{array}$ & 5.69 & \\
\hline Relationship & Purchasing price & 1.51 & 0.69 \\
\hline
\end{tabular}


Appendix B: Items used for the extension

\begin{tabular}{|c|c|c|c|}
\hline Construct & $\sqrt{20}$ & M & SD \\
\hline \multirow{4}{*}{$\begin{array}{l}\text { Expectation of } \\
\text { continuity }{ }^{\mathrm{a}, \mathrm{c}}\end{array}$} & We expect our relationship with the main supplier to continue for a long time & 6.18 & 0.82 \\
\hline & The renewal of our relationship with the main supplier is virtually automatic & 6.18 & 0.85 \\
\hline & Our relationship with the main supplier is enduring & 6.02 & 0.98 \\
\hline & Our relationship with the main supplier is a long-term alliance & 5.54 & 1.14 \\
\hline \multirow{6}{*}{$\begin{array}{l}\text { Business } \\
\text { performance }^{\text {b, c }}\end{array}$} & Sales growth & 5.54 & 1.01 \\
\hline & Profit growth & 5.36 & 1.09 \\
\hline & Overall profitability & 5.36 & 1.09 \\
\hline & Liquidity* & 5.13 & 1.23 \\
\hline & Labor productivity & 5.14 & 1.17 \\
\hline & Cash flow & 5.04 & 1.20 \\
\hline \multirow{4}{*}{$\begin{array}{l}\text { Reflective } \\
\text { indicators for } \\
\text { identification }\end{array}$} & RB1 - Overall, the main supplier provides us with benefits & 5.05 & 1.23 \\
\hline & $\begin{array}{l}\text { RB2 - All things considered, we gain benefits from our relationship with the } \\
\text { main supplier }\end{array}$ & 5.35 & 1.02 \\
\hline & $\begin{array}{l}\mathrm{RC} 1 \text { - Compared to the second-best supplier, our relationship with the main } \\
\text { supplier has costs }\end{array}$ & 2.62 & 0.97 \\
\hline & $\begin{array}{l}\mathrm{RC} 2 \text { - The costs of the main supplier are higher comparing to the second-best } \\
\text { supplier }\end{array}$ & 2.50 & 0.89 \\
\hline
\end{tabular}

a Seven-point scale with anchors $1=$ strongly disagree and $7=$ strongly agree

${ }^{\mathrm{b}}$ Seven-point scale with anchors $1=$ significantly worse than others in the industry and 7 = significantly better than others in the industry.

c Scales are adapted from Lush and Brown (1996).

${ }^{\mathrm{d}}$ Reflective items that were used for identification of the formative relationship benefits construct (RB1, RB2) and the formative relationship costs construct ( $\mathrm{RC} 1, \mathrm{RC} 2)$.

${ }^{a}$ Seven-point scale with anchors $1=$ strongly disagree and $7=$ strongly agree.

${ }^{\mathrm{b}}$ Five-point scale with anchors $1=$ my supplier's costs are much lower and $5=$ my supplier's costs are much higher.

c Product support and delivery are part of the "core offering".

d Service support and personal interaction are part of the "sourcing process".

. communication costs refer to "acquisition costs". Manufacturing costs and downtime costs are "operation costs" Note: Scale items not retained are indicated in parentheses. 
Figure 1: Comparison of studies: formative higher-order measurement results

Ulaga and Eggert (2006a)

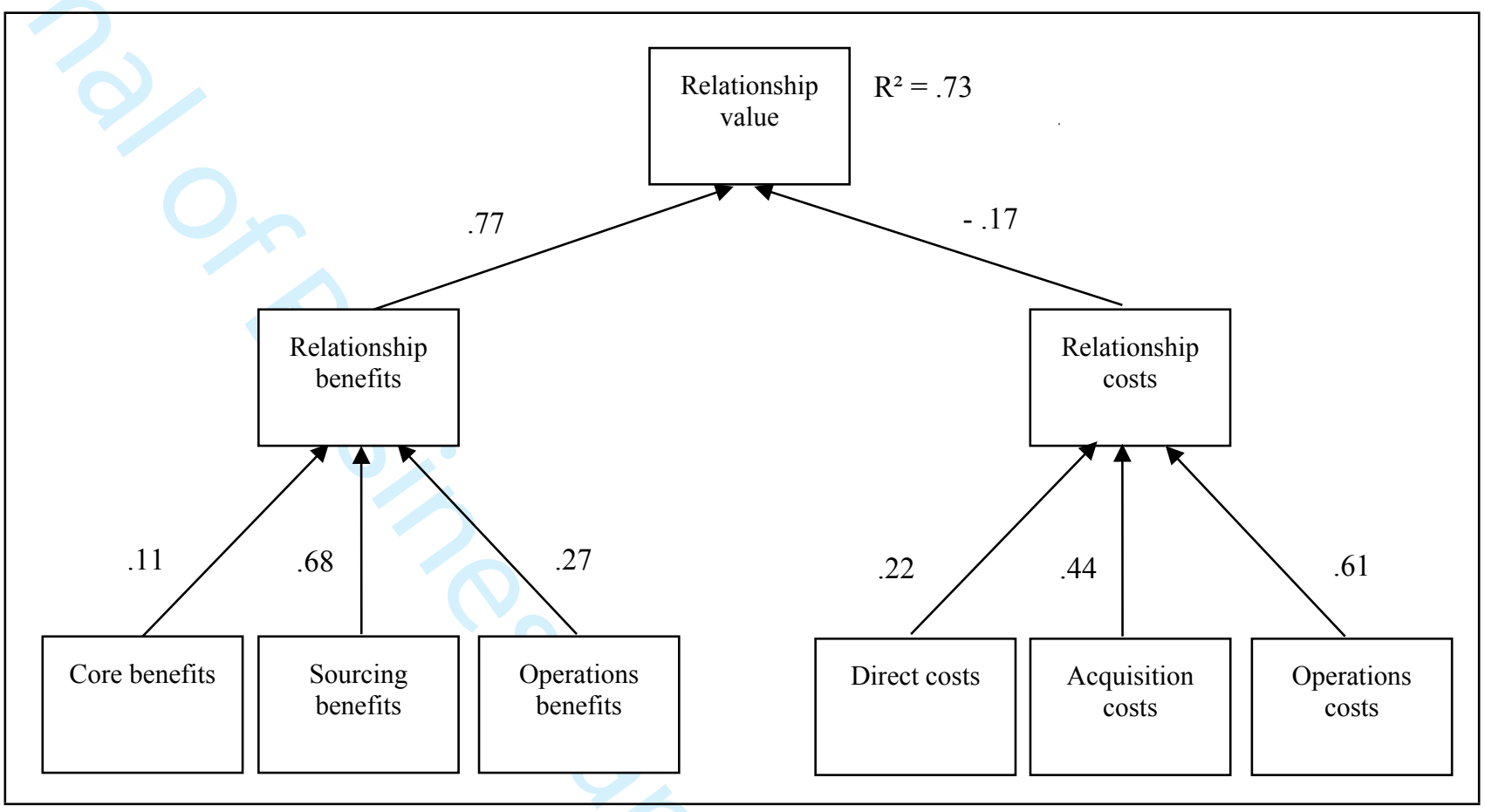

Replication study

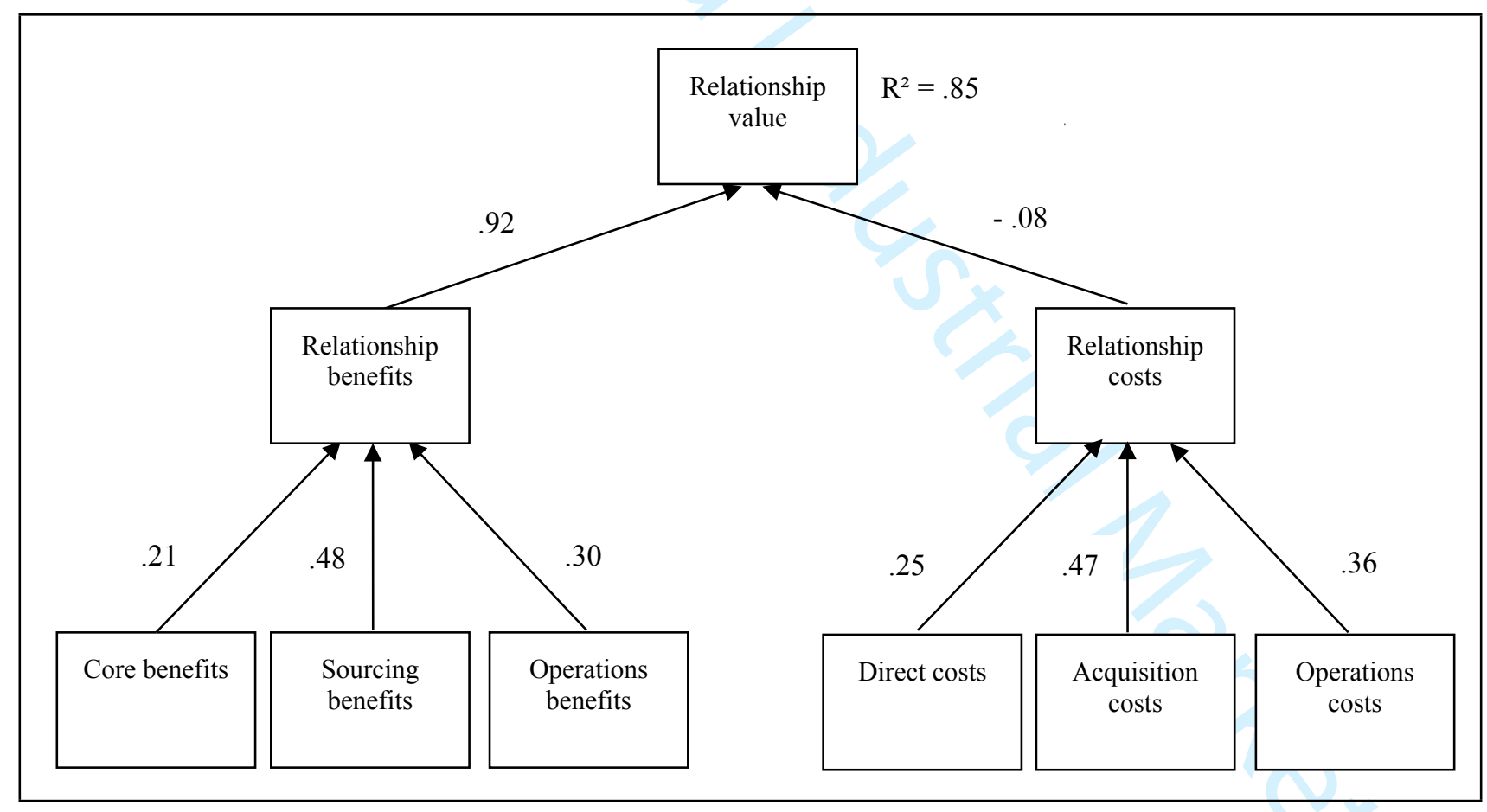

Note: Reported values are standardized coefficients (betas). $\mathrm{R}^{2}$ : explained variance in endogenous construct. All parameter estimates are significant at the .05 level. $\mathrm{n}=288$ (Ulaga and Eggert, 2006a); $\mathrm{n}=228$ (replication study) 
Table 1: Sample description

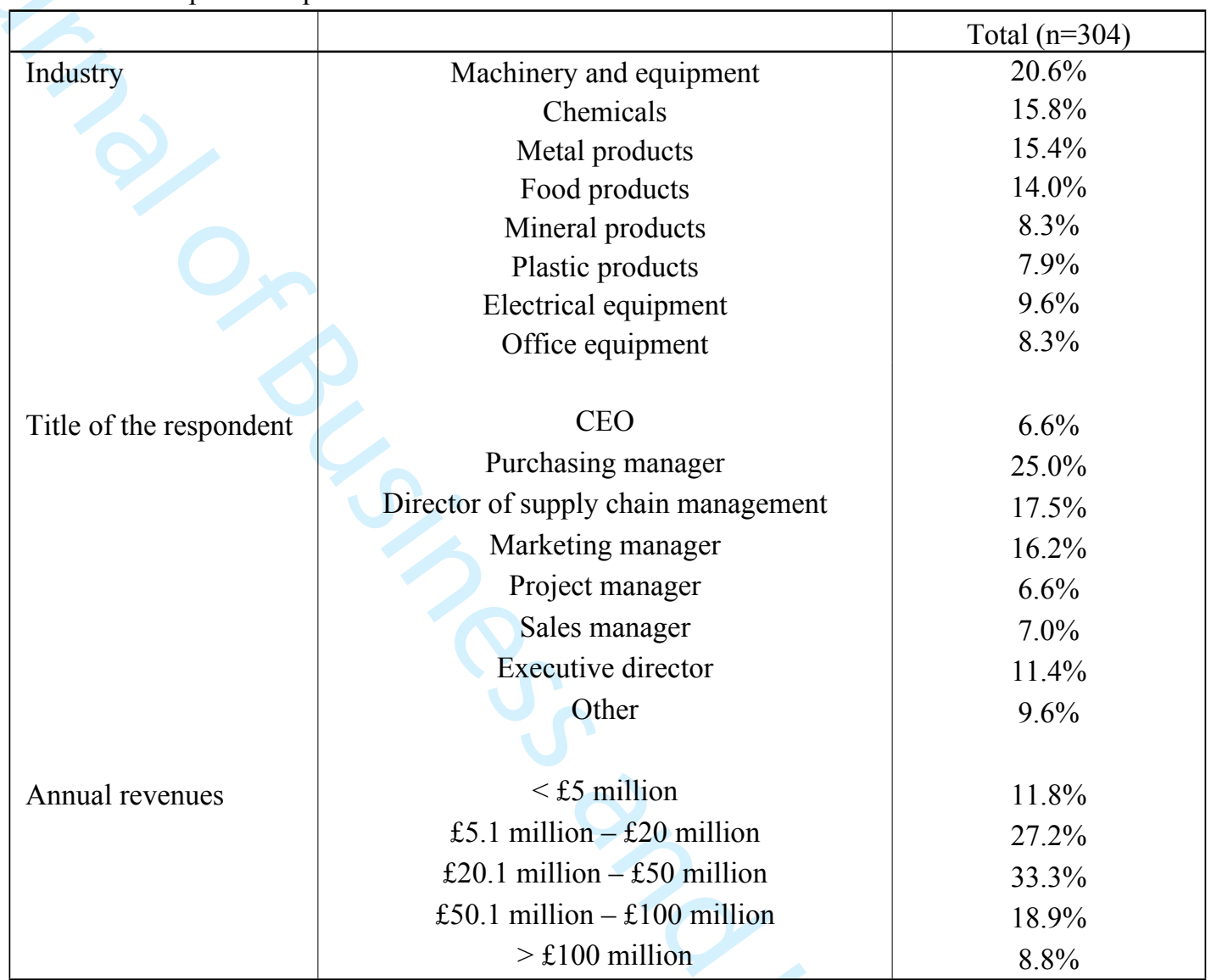


Table 2: Comparison of studies: value drivers' potential for differentiation in buyer-seller relationships

\begin{tabular}{|c|c|c|c|c|}
\hline \multirow[b]{3}{*}{ Sources of value creation } & \multicolumn{2}{|c|}{ Ulaga and Eggert (2006a) } & \multicolumn{2}{|c|}{ Replication study } \\
\hline & \multicolumn{2}{|c|}{ Relationship value dimensions } & \multicolumn{2}{|c|}{ Relationship value dimensions } \\
\hline & Benefits & Costs & Benefits & Costs \\
\hline Core offering & $\begin{array}{l}\text { Core benefits: } \\
.11 \times .77=\mathbf{. 0 8}\end{array}$ & $\begin{array}{c}\text { Direct costs: } \\
.22 \times .17=. \mathbf{0 3}\end{array}$ & $\begin{array}{l}\text { Core benefits: } \\
.21 \times .92=.19\end{array}$ & $\begin{array}{l}\text { Direct costs: } \\
.25 \times .08=\mathbf{. 0 2}\end{array}$ \\
\hline Sourcing process & $\begin{array}{l}\text { Sourcing benefits: } \\
.68 \times .77=.52\end{array}$ & $\begin{array}{l}\text { Acquisition costs: } \\
.44 \times .17=.07\end{array}$ & $\begin{array}{l}\text { Sourcing benefits: } \\
.48 \times .92=.44\end{array}$ & $\begin{array}{l}\text { Acquisition costs: } \\
.47 \times .08=\mathbf{. 0 4}\end{array}$ \\
\hline Customer operations & $\begin{array}{l}\text { Operations benefits: } \\
.27 \times .77=.21\end{array}$ & $\begin{array}{l}\text { Operations costs: } \\
.61 \times .17=. \mathbf{1 0}\end{array}$ & $\begin{array}{c}\text { Operations benefits: } \\
.30 \times .92=. \mathbf{2 8}\end{array}$ & $\begin{array}{c}\text { Operations costs: } \\
.36 \times .08=\mathbf{. 0 3}\end{array}$ \\
\hline Total & $.81 *$ & $.20 *$ & .91 & .09 \\
\hline
\end{tabular}

Note: Bold numbers show the variance explained by the formative value dimensions. They are derived by multiplying the path coefficients of the second-order dimensions by the coefficients of the respective first-order dimensions in Figure 1.

* In Ulaga and Eggert's (2006a) study benefits and costs do not add up to $100 \%$ because of rounding errors. 
Table 3: Extension: testing the relationship between relationship value and customer-focused relationship marketing outcomes

\begin{tabular}{lcc}
\hline Predictor variables & $\begin{array}{c}\text { Customer loyalty (expectation of } \\
\text { continuity) }\end{array}$ & Customer's business performance \\
\hline Core benefits & $.02(.16)$ & $.01(.06)$ \\
Source benefits & $.44^{*}(3.39)$ & $.11(.89)$ \\
Operations benefits & $.16(1.64)$ & $.34^{*}(3.64)$ \\
Direct costs & $-.10(-1.10)$ & $-.17^{* *}(-2.06)$ \\
Acquisition costs & $-.09(-.70)$ & $-.16(-1.32)$ \\
Operations costs & $-.22^{* *}(-2.35)$ & $-.03(-.33)$ \\
$\mathrm{R}^{2}$ & .23 & .25 \\
\hline
\end{tabular}

Note: Reported values are standardized coefficients (betas). The numbers in parentheses are $t$-values.

$\mathrm{R}^{2}$ : explained variance in endogenous construct.

${ }^{*} p<.01$

$* * p<.05$ 
Table 4: Configurational effects of relationship value on relationship marketing outcomes

\begin{tabular}{|c|c|c|c|}
\hline \multicolumn{4}{|c|}{ Solutions for high membership score in the outcome conditions } \\
\hline & \multicolumn{3}{|c|}{ Outcome condition } \\
\hline & Customer & ctation of & $\begin{array}{c}\text { Customer's business } \\
\text { performance }\end{array}$ \\
\hline Antecedent condition & 1 & 2 & 1 \\
\hline Core benefits & & & $\varnothing$ \\
\hline Source benefits & $\bullet$ & • & \\
\hline Operations benefits & & • & • \\
\hline Direct costs & • & & • \\
\hline Acquisition costs & $\varnothing$ & $\varnothing$ & \\
\hline Operations costs & • & $\bullet$ & $\varnothing$ \\
\hline Consistency & 0.85 & 0.89 & 0.87 \\
\hline Raw coverage & 0.48 & 0.53 & 0.56 \\
\hline Unique coverage & 0.04 & 0.03 & 0.01 \\
\hline Overall solution consistency & 0.85 & & \\
\hline Overall solution coverage & 0.76 & & \\
\hline
\end{tabular}

Black circles indicate the presence of a condition; circles with "/" ( $\varnothing$ ) indicate its absence; blank spaces indicate neutrality (i.e., no pattern of presence or absence was identified). Large circles indicate core conditions, and small ones, peripheral conditions. 
Table 5: Comparison of key findings and implications

\begin{tabular}{|c|c|c|}
\hline Ulaga and Eggert (2006a) & Replication study & Implications \\
\hline $\begin{array}{l}\text { Relationship value can be } \\
\text { measured as a multi-dimensional, } \\
\text { higher-order construct. Ulaga and } \\
\text { Eggert (2006a) proposed a } \\
\text { differentiation between benefits } \\
\text { and costs as key drivers of value } \\
\text { creation and three levels at which } \\
\text { these drivers operate (i.e., the core } \\
\text { offering, the sourcing process, and } \\
\text { the customer firm's internal }\end{array}$ & $\begin{array}{l}\text { The findings of the replication } \\
\text { study provide support for Ulaga } \\
\text { and Eggert's (2006a) } \\
\text { conceptualization of relationship } \\
\text { value as a higher-order construct } \\
\text { that consolidates a number of } \\
\text { relationship benefits and } \\
\text { relationship costs spanning the } \\
\text { three levels at which these drivers } \\
\text { operate }\end{array}$ & $\begin{array}{l}\text { Relationship value in business } \\
\text { markets is not merely a theoretical } \\
\text { construct viewed at a high level of } \\
\text { abstraction, but rather it can also be } \\
\text { empirically measured. This is } \\
\text { important because researchers in } \\
\text { this area have found difficulties } \\
\text { when it comes down to the } \\
\text { empirical assessment of } \\
\text { relationship value }\end{array}$ \\
\hline
\end{tabular}

Service support and personal interaction (i.e., the sourcing process) are found to be core differentiators, explaining nearly half the variance $(52 \%)$, followed by supplier's know-how and its ability to improve a customer's time to market (i.e. operation benefits), explaining $21 \%$ of the variance

Product quality and delivery performance (i.e., core benefits) are found to explain $8 \%$ of the variance, displaying a moderate potential for differentiation.

Ulaga and Eggert (2006a) support the idea that relationship benefits are more important than relationship costs. Relationship benefits are found to be nearly four times more important than costs (i.e. explained variances were $81 \%$ and $20 \%$ respectively).
The findings of the replication study support Ulaga and Eggert (2006a), suggesting that service support and personal interaction are core differentiators followed by supplier's know-how and its ability to improve a customer's time to market. The variances explained by each set of factors are also consistent with Ulaga and Eggert (2006a), though the discrepancy between them is relatively smaller. The core differentiators are found to explain $44 \%$ of the variance while the operation benefits explain $28 \%$ of the variance

Consistently with Ulaga and Eggert (2006a), product quality and delivery performance (i.e., core benefits) display a rather moderate potential for differentiation. However, the core benefits are found to explain $19 \%$ of the variance, a higher score than the Ulaga and Eggert (2006a) study

The replication study, consistently with Ulaga and Eggert (2006a), found that relationship benefits are more important than relationship costs. However, the results show a discrepancy between the "benefits vs. cost' scores. The replication study found that relationship benefits are nearly ten times more important than costs (i.e., explained variances were $91 \%$ and $9 \%$ respectively).
The findings indicate the increased importance of supplier reliability and service quality, especially as business markets are often mature and product differentiation becomes more difficult

Customers tend to perceive value mostly from solutions that integrate products and services into a functioning whole and the relational processes that improve customers' operations rather than product bundles. Core benefits appear to be a less important source of differentiation, compared to aspects that touch upon the sourcing process and operation benefits.

Customers seem more concerned about relationship benefits than cost considerations. Cost competitiveness is a necessary but not sufficient condition to differentiate in business markets. In other words, relationship benefits are more important than relationship costs when it comes to choosing the main supplier from a short list of potential suppliers. 